\title{
Current International Legal Issues: Philippines
}

\author{
Rommel J. Casis and Maria Pia Benosa*
}

\section{Treaties and Other International Agreements}

Philippine diplomacy is guided by the "Three Pillars of Philippine Foreign Policy" with the President as principal architect. These are the preservation and enhancement of national security, promotion and attainment of economic security, and the protection of the rights and promotion of the welfare of overseas Filipinos. Pursuant to these overarching goals, the Philippines negotiated and concluded several significant treaties, other international agreements, and arrangements in recent years.

The governments of the Philippines and the United States signed an Enhanced Defense Cooperation Agreement, ${ }^{1}$ following an earlier Status of Visiting Forces Agreement with Australia, ${ }^{2}$ bolstering defense partnership with the two countries. Within the region, negotiations with countries in the Association of South East Asian Nations (ASEAN) brought forth the ASEAN Charter, ${ }^{3}$ the legal and institutional framework for the regional organization - which ASEAN leaders signed in 2007 .

* Prof. Rommel Casis, Director, Institute of International Legal Studies, University of the Philippines (UP) Law Center, and Assistant Professor of Law, UP College of Law, and Prof. Maria Emilynda Jeddahlyn Pia V. Benosa, Professorial Lecturer, UP College of Law, and Law Education Specialist, UP Law Center. The contributors are Assistant Secretary J. Eduardo Malaya, Department of Foreign Affairs (for the sections on Treaties and other International Agreements; International Litigation and Adjudication); Prof. Emerson Bañez, Assistant Professor of Law, UP College of Law, and Head, Information and Publications Division, UP Law Center; Prof. Romel Regalado Bagares, Senior Consultant, Center for International Law (Philippines), and Professorial Lecturer, Lyceum of the Philippines University College of Law; Prof. Michael Tiu, Prof. Jacqueline Espenilla, Prof. Celeste Cembrano-Mallari, and Dr. Daniel Lising, Professorial Lecturers, UP College of Law, and Law Reform Specialists, UP Law Center.

1 Agreement Between the Government of the United States of America and the Government of the Republic of the Philippines on Enhanced Defense Cooperation, Phil.-U.S., opened for signature Apr. 28, 2014, T.I.A.S. No. 14-625 (entered into force June 25, 2014).

2 Agreement Between the Government of Australia and the Government of the Republic of the Philippines Concerning the Status of Visiting Forces of Each State in the Territory of the Other State, Austl.-Phil., opened for signature May 31, 2007, A.T.S. 31 (entered into force Sept. 28,2012 ).

3 Ass'n of Southeast Asian Nations [ASEAN] Charter, opened for signature Nov. 20, 2007 (entered into force Dec. 15, 2008). 
In the realm of trade and investment, the country entered into the Agreement on Comprehensive Economic Partnership Among the Member States of the Association of Southeast Asian Nations and Japan, ${ }^{4}$ the Framework Agreement on Partnership and Cooperation with the European Union, ${ }^{5}$ and a Free Trade Agreement with the European Free Trade Association, ${ }^{6}$ adding to the web of economic liberalization agreements aimed at facilitating economic engagements with partner countries. In 2018, the Philippines and China also signed several legal instruments, including some on the China-led Belt and Road Initiative, infrastructure-related arrangements, and oil and gas development.

The Philippines acceded on 14 July 2010 to the Hague Conference on Private International Law $(\mathrm{HCCH})$, an intergovernmental organization that develops and administers international conventions, protocols, and soft law instruments for the facilitation of cross-border transactions. Notably, the Philippines acceded to the HCCH Apostille Convention on 12 September 2018, which would serve to streamline cross-border document authentication processes, and benefit overseas Filipino workers (OFWs), with six out of ten major OFW destination countries being parties to the Convention.

In the field of protecting the rights and welfare of Filipino workers overseas, the country has prioritized the conclusion of bilateral labor agreements with labor-receiving countries, particularly in the Middle East. It took a leading role in the adoption of the Global Compact on Migration, ${ }^{7}$ a voluntary international framework that will manage migration and provide better treatment for millions of migrants worldwide.

On 12 September 2010, the Philippines acceded to the Convention for the Pacific Settlement of International Disputes, establishing the Permanent Court of Arbitration (PCA). ${ }^{8}$ In 2013, the Philippines came before the PCA, serving as

4 Agreement on Comprehensive Economic Partnership Among the Member States of the Association of Southeast Asian Nations and Japan, Mar. 26-Apr. 14, 2008, http://ajcep.asean.org/ wp-content/uploads/2014/05/Agreement.pdf.

5 Framework Agreement on Partnership and Cooperation Between the European Union and Its Member States, of the One Part, and the Republic of the Philippines, of the Other Part, opened for signature July 11, 2012, 2017 O.J. (L 343) 3 (entered into force Mar. 1, 2018).

6 Free Trade Agreement Between the EFTA States and the Philippines, opened for signature Apr. 28, 2016 (entered into force June 1, 2018), https://www.efta.int/sites/default/files/ documents/legal-texts/free-trade-relations/philippines/Philippines-EFTA-Main\%20 Agreement.pdf.

7 G.A. Res. 73/195, Global Compact for Safe, Orderly and Regular Migration (Dec. 19, 2018).

8 Convention for the Pacific Settlement of International Disputes, opened for signature Oct. 18, 1907, 32 Stat. 1779, T.S. 392, 1 Bevans 230 (entered into force Jan. 26, 1910). 
registry for an arbitral tribunal constituted under Annex VII of the UNCLOS ${ }^{9}$ in the South China Sea Arbitration against China. ${ }^{10}$

In 2017, the Philippines entered into 114 agreements. The more notable ones, indicative of priority areas for the Duterte Administration, include: the Paris Agreement on Climate Change, ${ }^{11}$ Defense Cooperation agreements with the Czech Republic ${ }^{12}$ and the Russian Federation, ${ }^{13}$ a Memorandum of Understanding with the Republic of Korea under the Employment Permit System, ${ }^{14}$ a Memorandum of Cooperation between the Philippine Coast Guard and the Japan Coast Guard, ${ }^{15}$ a Protocol to the ASEAN Charter on Dispute Settlement Mechanisms, ${ }^{16}$ and a Protocol on the Legal Framework to Implement the ASEAN Single Window ${ }^{17}$ which is "a regional initiative that connects and integrates National Single Window (NSW) of ASEAn Member States ... to expedite cargo clearance and promote ASEAN economic integration by enabling the electronic exchange of trade-related documents among ASEAN Member States." ${ }^{18}$

9 United Nations Convention on the Law of the Sea, opened for signature Dec. 10, 1982, 1833 U.N.T.S. 397 (entered into force Nov. 16, 1994) [hereinafter UNCLOS].

10 The South China Sea Arbitration (Phil. v. China), Case No. 2013-19, Award (Perm. Ct. Arb. 2016) [hereinafter South China Sea Arbitration Award].

11 Paris Agreement, opened for signature Apr. 22, 2016, U.N.T.S. 54113 (entered into force Nov. 4, 2016).

12 Press Release, Department of National Defense of the Philippines, Philippines and Czech Republic Sign Defense Cooperation Agreement (June 20, 2017), http://www.dnd.gov.ph/ PDF2017/DND-Press\%20-\%2oDefense\%2ocooperation\%2oagreement\%2obetween\%20 Philippines\%20and\%2oCzech\%20\%2oRepublic.pdf.

13 Russia andPhilippines Sign Military-TechnicalAgreement, Ministry of Defense of the Russian Federation (Oct. 24, 2017), http://eng.mil.ru/en/news_page/country/more. htm?id=12148115@egNews.

14 Memorandum of Understanding Between the Department of Labor and Employment, Republic of the Philippines and the Ministry of Labor, Republic of Korea on the Sending and Receiving of Workers Under the Employment Permit System of Korea, Phil.-S. Kor., May 30, 2009.

15 Memorandum of Cooperation Between the Philippine Coast Guard and the Japan Coast Guard, Japan-Phil., Jan. 12, 2017, https://pcoo.gov.ph/japan-ph-sign-several-agreements -to-enhance-bilateral-ties-12-jan-2017/.

16 Protocol to the ASEAN Charter on Dispute Settlement Mechanisms, opened for signature Apr. 8, 2010 (entered into force July 28, 2017), http://agreement.asean.org/media/ download/20160829075723.pdf.

17 Protocol on the Legal Framework to Implement the ASEAN Single Window, opened for signature Sept. 4, 2015 (entered into force Aug. 1, 2017), http://agreement.asean.org/media/download/20150915020056.pdf.

18 ASEAN Single Window, http://asw.asean.org/index.php (last visited Feb. 24, 2019). 


\section{International Litigation and Adjudication}

As a founding member of the United Nations and an adherent to the principle of peaceful settlement of disputes, the Philippines participated in litigation and arbitration involving issues related to foreign policy and international law ${ }^{19}$ in recent years.

Most notably, the Philippines brought its maritime disputes with China in the West Philippine Sea/South China Sea to international arbitration. As earlier mentioned, the South China Sea Arbitration was initiated by the Philippines in January 2013 under Part XV and Annex VII of the UNCLOS, and had the Permanent Court of Arbitration as its registry. ${ }^{20}$ The arbitration involved the characterization of certain maritime features and Chinese actions in the subject maritime area.

The Tribunal's award on the merits of said arbitration has significantly contributed to case law in the law of the sea, particularly in its discussions on the legal status of "historic rights" under the UNCLOS, parameters constituting an island under Articles 13 and 121 of the same convention, and the rights and duties of third States within a coastal State's exclusive economic zone. ${ }^{21}$ The Tribunal's pronouncements in its earlier Award on Admissibility ${ }^{22}$ have also been widely cited for providing valuable guidance on the duty to seek peaceful settlement of disputes, ${ }^{23}$ and the duty to enter into negotiations and exchange views. ${ }^{24}$

On 16 September 2014, the Philippines won its third investor-State arbitration concerning a decade-long dispute over an international airport terminal in Manila. The Philippines secured a complete dismissal on jurisdictional grounds of the claims of Fraport AG in proceedings before the International Centre for Settlement of Investment Disputes (ICSID). ${ }^{25}$

On 23 January 2017, the ICSID rendered a decision in Baggerwerken Decloedt En Zoon NV v. Republic of the Philippines, on the termination of a contract for

19 Digest of United States Practice in International Law 2014, U.S. DeP'T OF ST., https://www. state.gov/s/l/2014/ (last visited Feb. 24, 2019).

20 South China Sea Arbitration Award, supra note 10.

21 Id.

22 The South China Sea Arbitration (Phil. v. China), Case No. 2013-19, Award on Jurisdiction and Admissibility (Perm. Ct. Arb. 2015) [hereinafter Award on Jurisdiction and Admissibility].

23 UNCLOS, supra note 9, at 129-30.

24 Id. at 130.

25 Fraport AG Frankfurt Airport Services Worldwide v. Republic of the Phil., ICSID Case No. ARB 11/12, Award (Dec. 10, 2014), https://www.italaw.com/sites/default/files/case -documents/italaw4114.pdf. 
the rehabilitation of the Laguna Lake on the basis of a bilateral investment treaty between the Philippines and Belgium-Luxembourg. ${ }^{26}$

As a member of the World Trade Organization (WTO), the Philippines has abided by its commitments under international trade agreements and enforced its rights by, among others, participating in dispute settlement proceedings within the organization's ambit. As of this writing (January 2019), the Philippines is a party to 27 on-going wTо cases, including five cases in which it acts as complainant, notably those against Brazil, ${ }^{27}$ the United States, ${ }^{28}$ Australia, ${ }^{29}$ and Thailand. ${ }^{30}$

\section{Statehood, Jurisdiction of States, Organs of States}

The Philippines hopes to put a peaceful end to decades of Muslim insurgency in its southern region. An earlier attempt at a lasting settlement, through the creation of the Autonomous Region of Muslim Mindanao (ARMM), fell short of achieving lasting peace and development for the region's Muslim population. A Memorandum of Agreement on Ancestral Domain (MOA-AD), executed between the Philippine government and the Moro Islamic Liberation Front (MILF) on 5 August 2008, contemplated the expansion of the ARMM and the creation of a Bangsamoro Juridical Entity. The Philippine Supreme Court nullified the MOA-AD, citing the lack of transparency and consultation in its formation, and its violation of existing legislative policy on the rights of indigenous peoples. ${ }^{31}$ The Supreme Court also struck down a provision committing the government to amending the Constitution.

26 Baggerwerken Decloedt En Zoon NV v. Republic of the Phil., ICSID Case No. ARB 11/27, Award (Jan. 23, 2017), https://www.italaw.com/cases/5170.

27 Appellate Body Report and Panel Report, Brazil-Measures Affecting Desiccated Coconut, WTO Doc. WT/DS22/11/Rev.2 (June 6, 1997).

28 Request to Join Consultations, United States-Import Prohibition on Certain Shrimp and Shrimp Products, WTO Doc. WT/DS61/3 (Nov. 22, 1996).

29 Request for the Establishment of a Panel by the Philippines - Revision, Australia-Certain Measures Affecting the Importation of Fresh Fruit and Vegetables, WTO Doc. WT/DS270/5/ Rev.1 (July 11, 2003); Acceptance by Australia to Join Consultations, Australia-Certain Measures Affecting the Importation of Fresh Pineapple, WTO Doc. WT/DS271/4 (Nov. 12, 2002).

30 Notification of an Appeal, Thailand-Customs and Fiscal Measures on Cigarettes from the Philippines, WTO Doc. WT/DS371/27 (Jan. 14, 2019).

31 North Cotabato v. Republic of the Philippines, G.R. No. 183591 (S.C., Oct. 14, 2008) (Phil.), http://sc.judiciary.gov.ph/jurisprudence/2008/october2008/183591.htm. 
After a reconfiguration of the agreement with the MILF to comply with the Supreme Court decision, Congress passed the Bangsamoro Organic Law (воL). ${ }^{32}$ The воц creates a political entity called the Bangsamoro Autonomous Region which encompasses the current ARMM and subject to a plebiscite, additional cities and provinces in Mindanao, with powers beyond that of any local government corporation or any previous autonomous region.

The Bangsamoro will have a parliamentary government, empowered to enact laws on budgetary matters, the civil service, health, and education, among other matters subject only to the general supervision of the President. This power of supervision applies in case the Bangsamoro government violates the Constitution, national laws, and the Bangsamoro Organic Law. The BOL allows the administration of justice based on Shariah Law, which will apply to Muslims in the Bangsamoro. A case has been filed before the Supreme Court assailing the constitutionality of the law.

The Philippines is also considering shifting to a federal form of government. There are several pending draft constitutions under consideration, with different pathways for autonomy in Mindanao. The draft from a consultative committee formed by the President contemplated a Bangsamoro region along with another autonomous region in the north, and originally intended to include the воц as an attached ordinance. Another draft pending before Congress makes no express commitment for a Bangsamoro region. ${ }^{33}$

\section{International Environmental Law}

The Philippines became a State Party to the Convention on Biological Diversity $(\mathrm{CBD})^{34}$ on 8 October 1993. Since then, three protocols have been adopted under the CвD, on Biosafety, ${ }^{35}$ Access and Benefit-sharing, ${ }^{36}$ and on Liability and

$32 \quad$ An Act Providing for the Organic Law for the Bangsamoro Autonomous Region in Muslim Mindanao, Rep. Act No. 11054 (July 27, 2018) (Phil.), https://www.lawphil.net/statutes/ repacts/ra2018/ra_11054_2018.html.

33 Resolution of Both Houses No. 15, 17th Cong. (2018) (approved).

34 Convention on Biological Diversity, opened for signature June 5, 1992, 176o U.N.T.S. 69 (entered into force Dec. 29, 1993).

35 Cartagena Protocol on Biosafety to the Convention on Biological Diversity, opened for signature May 15, 2000, 2226 U.N.T.S. 208 (entered into force Sept. 11, 2003).

$36 \quad$ Nagoya Protocol on Access to Genetic Resources and the Fair and Equitable Sharing of Benefits Arising from Their Utilization to the Convention on Biological Diversity, opened for signature Feb. 2, 2011 (entered into force Oct. 12, 2014), https://treaties.un.org/doc/ Treaties/2010/11/20101127\%2002-08\%20PM/XXVII-8-b-Corr-Original.pdf. 
Redress. ${ }^{37}$ The Philippines ratified the Cartagena Protocol on 5 October 2006, and acceded to the Nagoya Protocol on 29 September 2015. Meanwhile, deliberations on Philippine accession to the Nagoya-Kuala Lumpur Supplementary Protocol, which provides for "international rules and procedures in the field of liability and redress relating to living modified organisms,"38 are ongoing.

While issues under the СвD and its Protocols are wide and varied, certain issues are of particular importance to the Philippines, given its geophysical features, location in the heart of marine biodiversity in the world, and limited resources and capability for technological advancement. These include the streamlining of efforts for climate change adaptation and mitigation, establishment of protected areas and designation of more Ecologically or Biologically Significant Marine Areas (EBSAs), and sustainable use of biodiversity. Access and benefit-sharing in relation to traditional knowledge, innovation, and practices are also important given the presence of diverse indigenous communities across the Philippines.

In 2015, typhoon victims, human rights groups, and concerned citizens petitioned the Commission on Human Rights (CHR) to investigate the activities of public- and privately-owned entities engaged in the production of fossil fuels, also known as "carbon majors." ${ }^{39}$ The $\mathrm{CHR}$ is the constitutionally-mandated body for investigating and monitoring all matters concerning human rights in the Philippines. Findings of this national inquiry, the last hearing of which was held in December 2018, are set to be published in June 2019. ${ }^{40}$ In a press release, the CHR expressed hope that the inquiry will "establish clear mechanisms and processes for hearing human rights cases, especially those imbued with extra-territorial obligations."11 It also anticipates that the report "would help to clarify standards for corporate reporting of carbon majors on their activities relating to greenhouse gas emissions, as well as help identify basic

37 Nagoya-Kuala Lumpur Supplementary Protocol on Liability and Redress to the Cartagena Protocol on Biosafety, opened for signature Mar. 7, 2011 (entered into force Mar. 5, 2018), https://treaties.un.org/doc/Treaties/2010/12/20101215\%2005-26\%20PM/Ch_27_8_c.pdf.

38 About the Nagoya - Kuala Lumpur Supplementary Protocol on Liability and Redress, ConVENTION ON BIOLOGICAL Diversity, https://bch.cbd.int/protocol/supplementary/ about/ (last visited Feb. 24, 2019).

39 Janvic Mateo, CHR to Hold Climate Change Inquiry on 'Carbon Majors,' Philstar GlobAL (Mar. 24, 2018, 12:00 AM), https://www.philstar.com/headlines/2018/03/24/1799803/ chr-hold-climate-change-inquiry-carbon-majors.

CHR Concluded Landmark Inquiry on the Effects of Climate Change to Human Rights; Expects to Set the Precedent in Seeking Climate Justice, Сомм'N оn Hum. RTs (Dec. 13, 2018), http://chr.gov.ph/chr-concluded-landmark-inquiry-on-the-effects-of-climate-change -to-human-rights-expects-to-set-the-precedent-in-seeking-climate-justice/. 
rights and duties relative to the impacts of climate change." ${ }^{\text {22 }}$ The Philippines has signed and ratified the UN Framework Convention on Climate Change, its Kyoto Protocol, and the Paris Agreement. The inquiry forms part of domestic and international efforts emphasizing that climate change is both an environmental and human rights issue, in view of challenges it poses against various protected rights. Related efforts to negotiate regulatory measures on marine debris and microplastics are also underway, following the Philippines' recent citation as being among the world's largest ocean polluters. ${ }^{43}$

\section{5}

\section{Human Rights}

\section{a Extrajudicial Killings and Summary Executions}

In November 2018 the Philippine Drug Enforcement Agency (PDEA) reported that 4,999 persons have been killed in the context of President Rodrigo Duterte's "War on Drugs" through "Oplan Tokhang" operations, from June 2016 to October $2018 .{ }^{44}$ However, human rights organizations and critics of the Administration estimate the figure to be closer to around 20,000 deaths. ${ }^{45}$ The Philippine National Police (PNP) claims that the use of deadly force had been necessary in a number of these cases, since drug suspects resisting arrest often endanger the lives of law enforcement officers. ${ }^{46}$ UN Special Rapporteur on extrajudicial, summary, or arbitrary executions Agnes Callamard has repeatedly expressed grave concern on the matter. ${ }^{47}$

While the PNP has acknowledged possible abuse by its law enforcement officers during the raids, and committed to investigating their liability, only one conviction has been secured in November 2018 against three police officers for

\footnotetext{
$42 \quad I d$.

43 Alixandra Vila, Philippines Plastic Pollution: Why So Much Waste Ends up in Oceans, S. China Morning Post (Oct. 18, 2018, 8:45 AM), https://www.scmp.com/lifestyle/health/ article/2168819/philippines-plastic-pollution-why-so-much-waste-ends-oceans.

44 Catherine Gonzales, PDEA: Almost 5,0oo Killed in Duterte's War on Drugs as of Oct. 2018, INQUIRER.NET (Nov. 27, 2018, 11:34 AM), https://newsinfo.inquirer.net/1057464/ pdea-almost-5000-killed-in-dutertes-war-on-drugs-as-of-oct-2018\#ixzz5gQNkiPAM.

45 Ted Regencia, Senator: Rodrigo Duterte's Drug War Has Killed 20,ooo, Al JAZEe RA (Feb. 22, 2018), https://www.aljazeera.com/news/2018/o2/senator-rodrigo-duterte-drug-war-killed -20000-180221134139202.html.

46 PNP Reports on Anti-Drugs Drive, Manila Bulletin (Dec. 20, 2017, 10:01 PM), https:// news.mb.com.ph/2017/12/20/pnp-reports-on-anti-drugs-drive/.

47 Callamard: Duterte 'Destroying Rule of Law,' ABS-CBN NEws (Sept. 27, 2018, 11:29 PM), https://news.abs-cbn.com/news/og/27/18/callamard-duterte-destroyed-rule-of-law.
} 
the murder of 17-year old victim Kian Loyd delos Santos. ${ }^{48}$ Earlier, in January 2017, the Supreme Court also granted the first Writ of Amparo in favor of survivor Efren Morillo, and families of victims of extra-judicial killings by officers of Quezon City Police District Station 6. The Writ of Amparo, an extraordinary remedy available to persons whose right to life, liberty, and security is violated or threatened, including victims of extra-legal killings and enforced disappearances or threats, was made permanent by the Philippine Court of Appeals in February 2017.

Two other petitions remain pending in the Supreme Court seeking Writs of Amparo and Prohibition against the implementation of "Oplan Tokhang," Almora v. Dela Rosa, and Daño v. Philippine National Police. Relevant documents ordered to be produced by the Supreme Court, including those on some 4,00o deaths of persons who allegedly resisted authority or arrest, could potentially serve as evidence in related proceedings concerning the War on Drugs before the International Criminal Court.

\section{b Threats to Freedom of Speech}

The Duterte administration passed a Freedom of Information mechanism in 2016 intended to provide transparency amid public criticism of governmental policies. ${ }^{49}$ Despite this, the human rights community finds that the right to freedom of speech is threatened in the country, with the stifling of dissent by public officials, private citizens, and even media organizations. Since President Rodrigo Duterte took office in 2016, opposition Senator Leila de Lima, also formerly the Commissioner of Human Rights and Secretary of Justice who launched investigations against the latter during his tenure as mayor, has been imprisoned on supposed drug-related charges. ${ }^{50}$ Supreme Court Chief Justice Maria Lourdes Sereno was likewise ousted through the unlikely legal mechanism of quo warranto, rather than constitutionally-prescribed impeachment (Republic of the Philippines v. Maria Lourdes P.A. Sereno, G.R. No. 237428, 11 May 2018). Rappler, an online media organization which has regularly published articles critical of the Duterte Administration, also had its operating license revoked, with tax evasion and cyber libel cases similarly being filed against its

48 Dharel Placido, Palace Lauds Conviction of Cops in Kian's Slay, ABS-CBN News (Nov. 29, 2018, 11:57 AM), https://news.abs-cbn.com/news/11/29/18/palace-lauds-conviction-of -cops-in-kians-slay.

49 Exec. Ord. No. 02 (Phil.).

50 Senator Leila de Lima Arrested in the Philippines, Al Jazeera (Feb. 25, 2017), https://www. aljazeera.com/news/2017/o2/leila-de-lima-arrested-philippines-170224003808389.html. 
founder, journalist Maria Ressa. The Committee to Protect Journalists has since tagged these incidents as a direct assault on press freedom in the Philippines. ${ }^{51}$

\section{c Non-Violent Discipline of Children}

The Philippine House of Representatives passed on final reading House Bill No. 8239 promoting positive and non-violent discipline of children. ${ }^{52}$ The bill, if passed into law, will protect children from physical, humiliating, or degrading acts as a form of punishment. Such acts include "any form of punishment or discipline in which physical force is used and intended to cause pain or discomfort or any non-physical act that causes children to feel belittled, denigrated, threatened, or ridiculed." ${ }^{53}$ Children will be protected from these acts in their homes, in schools, institutions, alternative care systems, the juvenile welfare system, places of religious worship, and in all other settings where there is direct contact with them.

The bill establishes reporting mechanisms and penalizes violations of the acts that could lead to charges under existing penal laws. It also stresses the role of government agencies concerned in the implementation of safeguards and protection measures. If passed into law, it constitutes significant compliance with international human rights obligations under the Universal Declaration on Human Rights (UDHR), ${ }^{54}$ and the Convention on the Rights of the Child. The latter instrument mandates States parties in Article 19 thereof to "take all appropriate legislative, administrative, social and educational measures to protect the child from all forms of physical or mental violence, injury or abuse, neglect or negligent treatment, maltreatment or exploitation, including sexual abuse, while in the care of parents, legal guardians, or any other person who has the care of the child."

\section{d State of Jails in the Philippines}

In October 2018, the House Committee on Human Rights conducted a motu proprio inquiry into the state of custodial facilities under the supervision of the

$5^{1} \quad$ Joel Simon \& Christophe Deloire, CPJ, RSF Call on Philippines to End its Persecution of Rappler and Maria Ressa, Сомм. то Рrотест Journalists (Nov. 26, 2018, 4:55 PM), https://cpj.org/2018/11/cpj-rsf-call-on-philippines-to-end-its-persecution.php.

An Act Promoting Positive and Non-Violent Discipline, Protecting Children from Physical, Humiliating or Degrading Acts as a Form of Punishment and Appropriating Funds Therefor, H.R. 8239, 17th Cong. (2018) (Phil.), http://www.congress.gov.ph/legisdocs/ first_17/CRoo861.pdf.

53 Id.

54 G.A. Res. 217 (III) A, Universal Declaration of Human Rights (Dec. 10, 1948). 
PNP, and possible violations of the human rights of persons under police custody (PUPC) due to prison overcrowding and inhumane living conditions. ${ }^{55} \mathrm{In}$ a letter to the Committee, the PNP Human Rights Affairs Office Chief raised concerns on the deplorable state of facilities for some 2,137 PUPCs, which translates to a 283.05 percent congestion rate in Metro Manila. ${ }^{56}$ Such congestion has made PUPCs especially susceptible to contagious diseases, resulting in the death of many while in their custodial cells. ${ }^{57}$

The Committee recommended the review of remedies and procedures that could lead to amendments to relevant laws, which should thereby be compliant with the Philippines' international human rights commitments. ${ }^{58}$ These include prohibitions against degrading and inhumane punishment under the UDHR, the UN Standard Minimum Rules for the Treatment of Prisoners, ${ }^{59}$ and the Body of Principles for the Protection of All Persons under Any Form of Detention or Imprisonment. ${ }^{60}$

In 2016 the Philippine Supreme Court denied an action for mandamus filed by British national Albert Wilson for the enforcement of a United Nations Human Rights Committee (HRC) Communication ${ }^{61}$ finding that reparations were due to him for violations of his rights under the ICCPR. ${ }^{62}$ Wilson complained, among others, of the inhumane and torturous conditions of his detention at a Valenzuela City Municipal Jail. ${ }^{63}$ The Court concluded, however, that views of the HRC do not form part of the ICCPR or its Optional Protocol, which are the treaties actually applicable within Philippine jurisdiction. Neither are they decisions per se which may be enforced outright, but are rather, "mere recommendations to guide the State it is issued against," which display "important characteristics of a judicial decision." 64

55 Press Release, House of Representatives of the Philippines, Committee on Human Rights Looks into Deplorable State of Jails (Oct. 3, 2018), http://www.congress.gov.ph/press/details.php?pressid=10954.

$56 \quad$ Id.

$57 \quad I d$.

58 Id.

59 U.N. Specialised Conferences, Standard Minimum Rules for the Treatment of Prisoners (Aug. 30, 1955).

$60 \quad$ G.A. Res. 43/173, U.N. Doc. A/43/173 (Dec. 9, 1988).

61 Wilson v. Philippines, Communication No. 868/1999, U.N. Doc. CCPR/C/79/D/868/1999 (2003).

62 G.A. Res. 2200A (XXI), International Covenant on Civil and Political Rights (Dec. 16, 1966).

63 Wilson v. Ermita, G.R. No. 189220 (S.C., Dec. 7, 2016) (Phil.).

64 Id. 
a Icc Prosecutor Preliminary Examination of the Philippine Situation In a statement dated ${ }_{13}$ October 2016, International Criminal Court (ICC) Prosecutor Fatou Bensouda expressed that her office is "aware of worrying reported extra-judicial killings of alleged drug dealers and users in the Philippines," which, at that time, had recorded about 3,00o deaths. ${ }^{65}$ The statement continued to say that the prosecutor is "deeply concerned about these alleged killings and the fact that public statements of high officials of the Republic of the Philippines seem to condone such killings and further seem to encourage State forces and civilians alike to continue targeting these individuals with lethal force."

The statement then made the legal point that "[e]xtra-judicial killings may fall under the jurisdiction of the International Criminal Court ... if they are committed as part of a widespread or systematic attack against a civilian population pursuant to a State policy to commit such an attack." This mirrors the language of the provision of the Rome Statute penalizing crimes against humanity.

After having received and reviewed communications and reports on alleged crimes punished under the Rome Statute, the ICc Office of the Prosecutor (ОтP), on 08 February 2018, opened a preliminary examination into the Philippine situation since at least o1 July $2016 .{ }^{66}$

In its 2018 Report on Preliminary Examination Activities, the отр discussed the procedural history of the examination, the preliminary jurisdictional issues which assert that the ICC has jurisdiction over Rome Statute crimes committed on the territory of the Philippines or by its nationals since 1 November 2011, and the contextual background of the preliminary examination that focused on the "war on drugs" waged by President Rodrigo Duterte, and the extrajudicial killings that have occurred since he took office. ${ }^{67}$

Describing the alleged crimes, the report states that the examination focuses on allegations that President Duterte and other senior government officials promoted and encouraged the killing of suspected or purported drug users

65 Int'l Crim. Ct., Statement of the Prosecutor of the International Criminal Court, Fatou Bensouda Concerning the Situation in the Republic of the Philippines (Oct. 13, 2016), https:// www.icc-cpi.int/pages/item.aspx?name=161013-otp-stat-php.

66 Int'l Crim. Ct., Statement of the Prosecutor of the International Criminal Court, Mrs Fatou Bensouda, on Opening Preliminary Examinations into the Situations in the Philippines and in Venezuela (Feb. 8, 2018), https://www.icc-cpi.int/Pages/item.aspx?name=180208-otp-stat.

67 Int'l Crim. Ct., Report on Preliminary Examination Activities (Dec. 5, 2018), https://www. icc-cpi.int/itemsDocuments/181205-rep-otp-PE-ENG.pdf. 
and/or dealers, and in such context, members of PNP forces and private individuals (such as vigilante groups) have carried out thousands of killings throughout the Philippines and in particular in the Metro Manila area. ${ }^{68}$

In light of the allegations and the reports, the отP, as stated in the report, continues to:

- conduct "a thorough factual and legal assessment of the information available in order to establish whether there is a reasonable basis to believe that the alleged crimes fall within the subject-matter jurisdiction of the [ICC]";69

- "gather, receive[,] and review information available from a wide range of sources on the crimes allegedly committed in the context of the "war on drugs' in the Philippines," ${ }^{70}$ and subject "such information to rigorous source evaluation, including assessment of reliability of sources and credibility of information received"; $; 1$

- "[focus] on recording, on an ongoing basis, relevant alleged incidents and examining the circumstances in which such incidents reportedly occurred and particular key features, such as in relation to the profile of alleged victims, the identity of the perpetrators and modus operandi employed" $;{ }^{72}$ and

- engage and consult "with relevant stakeholders, including by holding meetings at the seat of the [ICC]."73

The report concludes with the statement that the OTP will continue the preliminary examination and the assessment of the information available "in order to reach a determination on whether there is a reasonable basis to believe that the alleged crimes fall within the subject-matter jurisdiction of the Court."74

\section{b Philippines Withdraws from the Icc}

On 16 March 2018 the Philippines, which signed the Rome Statute on 28 December 2000 and deposited its instrument of ratification on 30 August 2011, formally transmitted its notice of withdrawal from the ICC to the office of the United Nations (UN) Secretary-General in New York. ${ }^{75}$ In its Note Verbale, the Permanent Mission to the United Nations conveyed that:

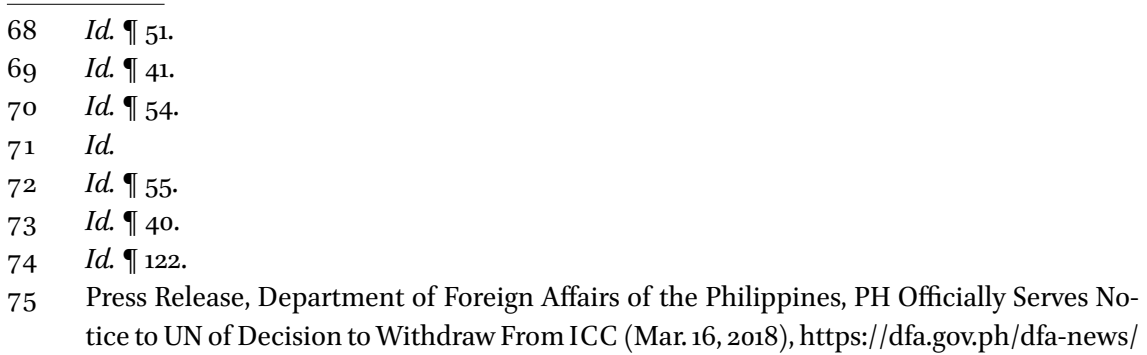


The Government affirms its commitment to fight against impunity for atrocity crimes, notwithstanding its withdrawal from the Rome Statute, especially since the Philippines has a national legislation punishing atrocity crimes. The Government remains resolute in effecting its principal responsibility to ensure the long-term safety of the nation in order to promote inclusive national development and secure a decent and dignified life for all.

The decision to withdraw is the Philippines' principled stand against those who politicize and weaponize[d] human rights, even as its independent and well-functioning organs and agencies continue to exercise jurisdiction over complaints, issues, problems and concerns arising from its efforts to protect its people. ${ }^{76}$

This step follows the procedure outlined in Article 127 (1) of the Rome Statute. ${ }^{77}$ In that provision, the effectivity of the withdrawal shall occur one year after the date of receipt of the notification, unless the notification specifies a later date.

The Note Verbale dated 15 March 2018 informs the UN Secretary-General "of the decision of the Government of the Republic of the Philippines to withdraw from the Rome Statute of the International Criminal Court in accordance with the relevant provisions of the Statute." ${ }^{78}$ In a statement following the transmittal of the notice, President Duterte disputed that the ICC had acquired jurisdiction over the alleged acts committed by his administration. ${ }^{9}$

The ICC, in a statement released on 20 March 2018, acknowledged that on 19 March 2018, it was officially notified by the United Nations that the Philippines had deposited a written notification of withdrawal from the Rome Statute,

dfa-releasesupdate/15975-ph-officially-serves-notice-to-un-of-decision-to-withdrawfrom-icc.

76 Letter from the Secretary of Foreign Affairs of the Philippines to the Secretary-General of the U.N. (Mar. 19, 2018), https://treaties.un.org/doc/Publication/CN/2018/CN.138.2018Eng.pdf.

77 Rome Statute of the International Criminal Court, opened for signature July 17, 1998, 2187 U.N.T.S. 3 (entered into force July 1, 2002).

78 Philippine Mission to the U.N., Note Verbale Dated Mar. 18, 2018 from the Philippine Mission to the United Nations Addressed to the U.N. Secretary-General, No. ooo181-2018 (Mar. 18, 2018).

79 Full Text: Duterte's Statement on Int'l Criminal Court Withdrawal, RAPPLE R (Mar. 14, 2018, 07:20 PM), https://www.rappler.com/nation/198171-full-text-philippines-rodrigo-duterte -statement-international-criminal-court-withdrawal. 
with the United Nations Secretary-General as the depositary of the Statute. ${ }^{80}$ The ICC expressed its regrets regarding this development and continued to encourage the Philippines to remain part of the ICc. Nevertheless, it also recognized that " $[w]$ ithdrawing from the Rome Statute is a sovereign decision, which is subject to the provisions of article 127 of that Statute."81 It then made a statement that this withdrawal does not have an impact on "on-going proceedings or any matter which was already under consideration by the Court prior to the date" of the effectivity of the withdrawal. ${ }^{82}$ Such action, according to the ICC, also does not affect the status of any judge already serving at the ICC.

The Executive's withdrawal from the ICC has not gone unchallenged before the Philippine Supreme Court. Oral arguments in consolidated petitions filed by six incumbent senators, and the Philippine Coalition for the International Criminal Court, were concluded in August 2018. ${ }^{83}$ Resolution of the case largely depends on a determination of the necessity of Senate participation in withdrawal from treaties - a point on which the Philippine Constitution is silent.

\section{International Cooperation}

a Mutual Legal Assistance Treaty

The Philippines is a labor-sending state which largely depends on remittances of overseas Filipino workers (OFWs) for more than $20 \%$ of its export earnings and more than $5 \%$ of its gross national product (GNP). In view of this dependence on migration, the Philippines committed itself to several mutual legal assistance treaties to better protect the interests of its citizens, pursue absent or absconding suspects, and collect pertinent evidence with the assistance of other States parties.

On 12 December 2008, the Philippines became a party to the 2004 Treaty on Mutual Legal Assistance in Criminal Matters among States in the ASEAN. The Treaty covers mutual assistance among member countries in facilitating the taking of evidence or voluntary statements from persons, and effecting service of judicial documents, among others.

\footnotetext{
8o Press Release, International Criminal Court, ICC Statement on the Philippines' Notice of Withdrawal: State Participation in Rome Statute System Essential to International Rule of Law (Mar. 20, 2018), https://www.icc-cpi.int/Pages/item.aspx?name=pr1371.

$81 \quad I d$.

$82 \quad I d$.

83 Amended Advisory, Pangilinan v. Cayetano, G.R. No. 238875 \& PCICC v. Madialdea, G.R. No. 239483 (S.C., Aug. 28, 2018) (Phil.).
} 
The Philippines is also a party to thirteen extradition treaties. Most of these treaties use the non-list dual criminality approach as a means of determining whether a person-of-interest can be subjected to extradition. Under the said system, the conduct on which a petition for extradition is based must be an offense in both States. Contrary practice is embodied in the extradition treaties with two other ASEAN Member States, Indonesia, ${ }^{84}$ and Thailand, ${ }^{85}$ under which the list dual criminality approach is used. Under the latter, extraditable offenses are expressly listed, and no extradition can be granted for offenses outside the same.

\section{b Prevention of Pandemic Influenza and Other Dangerous Communicable Disease}

In the period between January 1918 and December 1920, 500 million people around the world contracted the $\mathrm{H}_{1} \mathrm{~N}_{1}$ influenza virus, resulting in the deaths of 50 to 100 million people. Persons afflicted include people from such remote areas as the Pacific Islands and the Arctic. Since that time, there have been multiple near misses in infectious disease outbreaks, including the Avian Influenza A, SARs, MERs, Ebola, and Zika virus. Coupled with increasing global trade and travel, the danger of a recurrence of the Spanish Flu of 1918 is something States ought to pay attention to. The Philippines is at particular risk for these types of illnesses, in view of its active promotion of tourism as a source of revenue. Coupled with the lack of universal access to health care, an outbreak of illness like the pandemic flu would be devastating to the Philippine public. The rate of migration of Filipino citizens likewise increases the risk of spreading such illnesses to receiving States.

One of the means by which the Philippines has addressed this concern is through participation in the Pandemic Influenza Preparedness Framework, a non-binding agreement negotiated by the wHO governing the sharing of influenza viruses with a pandemic potential, to spur the rapid development of vaccines and countermeasures. ${ }^{86}$

84 Extradition Treaty Between the Republic of Indonesia and the Republic of Philippines, Indon.-Phil., Feb. 10, 1976, http://www.oecd.org/site/adboecdanti-corruptioninitiative/ 39797304.pdf.

85 Treaty Between the Government of the Kingdom of Thailand and the Government of the Republic of the Philippines Relating to Extradition, Phil.-Thai., Mar. 16, 1981, http://www. oecd.org/site/adboecdanti-corruptioninitiative/39816273.pdf.

86 Pandemic Influenza Preparedness Framework for the Sharing of Influenza Viruses and Access to Vaccines and Other Benefits, World Health Organization (May 24, 2011), http://apps.who.int/gb/pip/pdf_files/pandemic-influenza-preparedness-en.pdf. 
The South China Sea Arbitration (Philippines v. China) Under Annex VII of the UNCLOS

On 22 June 2013, the Philippines initiated arbitration against China under Annex VII to the UNCLOS. ${ }^{87}$ The Philippines sought a ruling that would specifically address China's claims to disputed waters within a unilaterally declared "Nine-Dash Line," the legal character of various maritime features in that area, and China's breaches of the UNCLOS. Despite China's refusal to participate in the proceedings, the arbitration continued in accordance with Article 9 of Annex VII, with only the Philippines appearing as a Party.

After determining that it had jurisdiction to hear the case, ${ }^{88}$ the arbitral tribunal gave the Philippines a sweeping legal victory. It invalidated China's claim to "historic rights" in the South China Sea - the basis for its "Nine-Dash Line" policy - and declared that China had abandoned such claims after it signed and ratified the UNCLOs. ${ }^{89}$ Notably, the award also clarified the status of the various land features in the disputed area. ${ }^{90}$ It found that none of them were "islands" capable of generating their own exclusive economic zone (EEZ), and that many of them were not even "rocks" that would entitle their claimant to a territorial sea. ${ }^{91}$ Consequently, a number of the features analyzed by the arbitral tribunal were properly found to be within the Philippines' EEZ and not subject to any possible Chinese entitlement. ${ }^{92}$

The arbitral tribunal also found that China breached its obligations under the UNCLOS when: (1) it interfered with Philippine fishing and petroleum activities in the Philippines' own EEZ, (2) it constructed artificial islands, thereby causing significant marine environmental damage to the area, (3) it engaged in dangerous maneuvering against Philippine ships, and (4) it failed to prevent Chinese fishermen from engaging in destructive fishing practices in the Philippine EEz. ${ }^{93}$ Specifically, China violated its obligations to recognize and respect the Philippines' sovereign rights over its EEZ, to protect and preserve the marine environment, to refrain from taking actions that cause permanent damage

\footnotetext{
87 South China Sea Arbitration Award, supra note 10.

88 Award on Jurisdiction and Admissibility, supra note 22.

89 South China Sea Arbitration Award, supra note 10.

9o Id.

$91 \quad$ Id.

$92 \quad I d$.

$93 \quad I d$.
} 
and irreparable harm to the marine environment, and to exercise restraint and not aggravate the dispute. ${ }^{94}$

\section{b Successful Claim to an Extended Continental Shelf in the Benham Rise Region}

The Benham Rise Region (BRR) is a 13-million hectare area off the northeastern coast of Luzon, the country's largest island. It is the "natural submarine prolongation of the Luzon Island extending up to 318 nautical miles (589 kilometers), from the Eastern Philippine Seaboard facing the Pacific Ocean." ${ }^{95}$ The BRR is "geomorphologically distinct from the deep ocean floor and forms a thick crust lying at about 3,000-3,500 meters below sea level, except for the Benham Bank, its shallowest point, which towers up to 48-70 meters below sea level. ${ }^{\text {96 }}$ During previous explorations of the BRR, government scientists found that the area exhibited rich biodiversity due to the presence of a thick and virtually pristine coral cover, which in turn sustains over 200 species of fish, as well as an unidentified number of algae and sponges. They further observed that the BRR is a spawning ground for tuna, and has the potential to yield the country's highest catch rate for the species. ${ }^{97}$ The seabed is also thought to contain a number of important mineral resources, including gas hydrates and cobalt-rich ferromanganese crusts. ${ }^{98}$

On 8 April 2009, the Philippines submitted to the United Nations Commission on the Limits of the Continental Shelf (CLCS) its claim to an extended continental shelf in the в RR. ${ }^{99}$ In accordance with Article 76, paragraph 8, of the UnCLOS, the Philippine submission contained information showing the limits of the continental shelf beyond 200 nautical miles from the baselines from which the breadth of the territorial sea is measured. On 12 April 2012, the CLCS adopted by consensus its Recommendations, effectively confirming the country's claim. ${ }^{100}$

\footnotetext{
$94 \quad I d$.

95 Foreign Service Institute, The Philippine Rise, Think-AsIA, www.fsi.gov.ph/wp-content/ uploads/2017/12/The-Philippine-Rise.pdf (last visited Feb. 25, 2019).

$96 \quad I d$.

$97 \quad I d$.

$98 \quad I d$.

99 Commission on the Limits of the Continental Shelf (CLCS) Outer Limits of the Continental Shelf Beyond 200 Nautical Miles from the Baselines: Submissions to the Commission: Submission by the Republic of the Philippines, U.N. Div. for Ocean Aff. \& the L. of the SeA (July 19, 2012), https://www.un.org/Depts/los/clcs_new/submissions_files/submission_ phl_22_2009.htm.

100 Recommendations of the Commission on the Limits of the Continental Shelf in Regard to the Submission Made by the Philippines in Respect of the Benham Rise Region on 8 April 2009,
} 
Notwithstanding the UN's recognition of the Philippines' sovereign rights over the BRR, the International Hydrographic Organization (IHO) still approved China's proposal to name five of the underwater features located in the area. ${ }^{101}$ China's move was the direct result of unsanctioned underwater surveys that it conducted in the BRR in 2004. Although the Philippines did not file a formal protest against China, it nonetheless raised its objections during the meeting of the Philippines-China Bilateral Consultative Mechanism held on 13 February 2018. Prior to this, President Rodrigo Duterte renamed the Benham Rise to "Philippine Rise" for purposes of reinforcing the country's claim to sovereign rights. ${ }^{102}$

In 2018, President Duterte also formally declared ${ }^{103}$ the portion of the Philippine Rise located within the country's exclusive economic zone (EEZ) as the "Philippine Rise Marine Resource Reserve" (PRMRR) under the National Integrated Protected Area Systems (NIPAS) Act. ${ }^{104}$ The PRMRR is comprised of two distinct areas: a 49,684 hectare Strict Protection Zone and a 302,706 hectare Special Fisheries Management Area. The former is effectively a "no take" zone due to the importance of preserving the undisturbed state of the marine environment for purposes of scientific study, environmental monitoring, and for the maintenance of genetic resources. The latter is technically open to commercial fishing but subject to a stringent management plan designed to prevent illegal, unreported, and unregulated (IUU) fishing, and to promote the sustainable utilization of the marine resources in the area.

\section{c Maritime Boundary Delimitation with Indonesia}

In August 2018, hearings resumed in the Philippine Senate on the body's concurrence in the country's ratification of the maritime boundary agreement signed on 23 May 2014 delimiting its exclusive economic zone from that of Indonesia in the Sulu-Celebes Sea Area. The Agreement was ratified by then President Benigno Aquino III in 2015, and has been pending in the Senate Committee of Foreign Relations since January 2016. It is the product of twenty years of negotiations, and builds on the findings and doctrines enunciated in

Commission on the Limits of the Continental Shelf (Apr. 12, 2012), https:// www.un.org/Depts/los/clcs_new/submissions_files/phl22_09/phl_rec.pdf.

101 Frances Mangosing \& Leila B. Salaverria, Palace Objects to China Naming PH Rise Features, INQUIRER.NET (Feb. 15, 2018, 07:00 AM), http://globalnation.inquirer.net/164203/ palace-objects-china-naming-ph-rise-features.

102 Exec. Ord. No. 25 (Phil.).

103 Proc. No. 489 (Phil.).

104 An Act Providing for the Establishment and Management of National Integrated Protected Areas System, Defining Its Scope and Coverage, and for Other Purposes, Rep. Act No. 7586, O.G. (June 1, 1992) (Phil.). 
the landmark Island of Palmas arbitration between the two States' colonial predecessors, the United States and the Netherlands. ${ }^{105}$ While concurrence to the boundary agreement's ratification is already approved in principle, lawmakers continue to cite as problematic the frequent detention of Filipino fishermen, and interdiction of Philippine-flagged vessels in Indonesia, for alleged violations of fisheries laws along the two States' porous maritime border.

The Philippines and Indonesia have likewise entered into a Trilateral Cooperation Agreement (TCA) with Malaysia on 14July 2016, for the conduct of joint naval and air patrols and enhanced information-sharing, to combat acts of armed robbery, kidnapping, piracy, and terrorism in the tri-border area in the Sulu Sea. ${ }^{106}$ The coordinating mechanisms employed by the three States under the TCA are often credited as instrumental to the decrease of incidents of armed robbery and piracy in the region.

\section{d Proposed Legislation on Maritime Affairs}

To date, several bills remain pending before the relevant Senate committees of the 17th Congress, geared at promoting the Philippines' full compliance with its commitments under the Law of the Sea and international maritime law. These include bills for a Maritime Safety, Security, and Prevention of ShipSourced Pollution Act, ${ }^{107}$ and a Department of Maritime Affairs Act. ${ }^{108}$

Two other bills that have been pending before the Committee on Foreign Relations since 2016 are particularly pertinent to the State's exercise of rights in maritime areas under its national jurisdiction. At the most basic level, the proposed Philippine Archipelagic Sea Lanes Act ${ }^{109}$ and Philippine Maritime Zones Act ${ }^{110}$ both purport to clarify ambiguities that may have resulted from the piling on of territorial treaties, the entry into force of the UNCLOS, the archipelagic doctrine, the South China Sea Arbitration Award, and inexact Constitutional and statutory language on the national territory and maritime jurisdiction. Legislators, executive officials, and law enforcement officers alike must, however, tread the process carefully, since enacting either or both pieces of legislation would potentially reduce the breadth of Philippine jurisdictional rights, and require vast human and material resources for the maintenance of security in the subject maritime zones.

\footnotetext{
105 Island of Palmas Case (Neth. v. U.S.), 2 U.N. Rep. of Int'l Arb. Awards 829 (Apr. 4, 1928).

106 Press Release, Department of National Defense of the Philippines, Defense Ministers Affirm Trilateral Cooperative Agreement (Aug. 3, 2016), http://www.dnd.gov.ph/PDF\%20 2016/Press\%20-\%2oTrilateral\%2oMeeting\%2oStatement.pdf.

107 S. 2135, 17th Cong. (2018) (Phil.).

108 S. 477, 17th Cong. (2016) (Phil.).

109 S. 92, 17th Cong. (2016) (Phil.).

110 S. 93 , 17th Cong. (2016) (Phil.).
} 